\title{
Evaluation of Application Methods of Metam Sodium for Management of Fusarium Crown and Root Rot in Tomato in Southwest Florida
}

\author{
R. J. McGovern, University of Florida-IFAS, Gulf Coast Research and Education Center, Bradenton 34203-9324; \\ C. S. Vavrina, University of Florida-IFAS, Southwest Florida Research and Education Center, Immokalee 34143- \\ 5002; J. W. Noling, University of Florida-IFAS, Citrus Research and Education Center, Lake Alfred 33850-2299; \\ L. A. Datnoff, University of Florida-IFAS, Everglades Research and Education Center, Belle Glade 33430-8003; \\ and H. D. Yonce, Zeneca Ag Products, Deland, FL 32720
}

\begin{abstract}
McGovern, R. J., Vavrina, C. S., Noling, J. W., Datnoff, L. A., and Yonce, H. D. 1998. Evaluation of application methods of metam sodium for management of Fusarium crown and root rot in tomato in southwest Florida. Plant Dis. 82:919-923.

Experiments were conducted during 1992 to 1995 to evaluate the effectiveness of application methods of metam sodium (MS; sodium $N$-methyldithio-carbamate) for the management of Fusarium crown and root rot (FCRR) caused by Fusarium oxysporum f. sp. radicis-lycopersici in mulched and staked tomatoes (Lycopersicon esculentum Mill.) grown on raised beds in commercial fields in southwest Florida. Efficacy of MS was compared with soil-injection of methyl bromide-chloropicrin (MBC), the current industry practice for production of tomatoes in Florida. The incidence of FCRR was consistently high in nontreated plots (80 to 100\%), but disease severity varied by site, and yields were reduced by 10 to $57 \%$ at sites with high disease severity when compared to sites treated with MBC at 336 to $448 \mathrm{~kg} / \mathrm{ha}$. Application of MBC reduced FCRR incidence in all experiments. Chemigation with MS at 701 or 935 liters/ha into mulched beds using either one or two drip irrigation tubes placed on the soil surface, and soil injection of MS at 935 liters/ha, failed to reduce the disease. The application of MS at 935 liters/ha to the soil surface prior to bed formation produced variable results. Rotovation of MS at the same rate into preformed beds consistently produced reductions in the incidence of FCRR equivalent to those achieved by MBC.
\end{abstract}

Additional keywords: fumigation, methyl bromide, sodium $N$-methyldithio-carbamate

Fresh market tomato is a major vegetable crop (valued at $\$ 440$ million during 1995 to 1996) in Florida, where the southwest region accounted for $38 \%$ of statewide production (4). Fusarium crown and root rot (FCRR) of tomato, caused by Fusarium oxysporum f. sp. radicislycopersici, has been the most prevalent soilborne disease of tomato in this area during the past 6 years; up to $30 \%$ plant mortality was commonly observed in a number of fields during severe outbreaks of the disease in 1991 and 1992 (R. J. McGovern, unpublished data). In addition, the disease has been estimated to cause yield losses of 15 and $29 \%$ in west-central and southeastern Florida, respectively $(12,28)$. First detected in Florida during the

Corresponding author: R. J. McGovern E-mail: rjm@gnv.ifas.ufl.edu

This research was funded by grants from the Florida Tomato Exchange, Florida Fruit and Vegetable Association, and the USDA. Florida Agricultural Experiment Station Journal Series No. R-05881.

Accepted for publication 24 April 1998.

Publication no. D-1998-0615-03R

(C) 1998 The American Phytopathological Society
1974 to 1975 season (28), FCRR also has been reported in Canada, Israel, Japan, Mexico, many countries in Europe, and other states in the United States, including California, New Jersey, New York, New Hampshire, Ohio, Pennsylvania, and Texas (9). The disease poses a significant threat to tomato transplant production and to both field and greenhouse fruit production wherever it occurs $(9,17)$.

External symptoms of FCRR in mature plants include brown discoloration and rot at the soil level in the crown and roots. The lower leaves of infected plants turn yellow and the entire plant may wilt around the time of first harvest. The tap root of infected plants often rots entirely. When diseased plants are sectioned lengthwise, extensive brown discoloration and rot are evident in the cortex of crowns and roots.

Fumigation with methyl bromide-chloropicrin (MBC) formulations has been the most commonly used preplant practice for control of Fusarium crown rot and other soilborne pests of tomato in Florida for the past 10 to 15 years. However, methyl bromide has recently been categorized as a Class I ozone-depleting substance by the Montreal Protocol (an international treaty promulgated by the United Nations Environmental Programme), and it faces removal by the United States Environmental
Protection Agency under the auspices of the Clean Air Act by the year 2001 $(31,32)$. This situation necessitates development of alternative management strategies for FCRR and other soilborne pests, including the use of other fumigants.

Soil injection of metam sodium (MS; sodium $N$-methyldithio-carbamate) by means of chisels at 462 liters/ha failed to reduce FCRR in an artificially infested field in west-central Florida (11). Application of MS through a drip irrigation system (chemigation) significantly reduced plantparasitic nematodes in tomato but failed to provide adequate control of Fusarium wilt and nutsedge (Cyperus sp.) in Florida (20,21), and reduced Fusarium spp., Pythium ultimum, and root-knot nematodes (Meloidogyne spp.) in carrot (Daucus carota) and tomato roots in California (23). MS had greater or equal efficacy against Rhizoctonia solani and Pythium spp. in a number of vegetable crops when applied by overhead sprinkler irrigation rather than soil injection (29).

The objective of the current research was to compare the effectiveness of different methods of applying MS with MBC for management of FCRR and other soilborne pests as they occurred in commercial tomato production fields.

\section{MATERIALS AND METHODS}

General experimental procedures. Five tomato fields (Pomello fine sand) naturally infested with $F$. oxysporum f. sp. radicislycopersici on four commercial farms in Immokalee in southwest Florida were chosen for evaluation of MS during 1992 to 1995 based on previously high crown rot incidences. MBC formulations had been used as the routine preplant sterilant on all sites for varying periods based on their individual cropping histories.

The evaluated delivery methods for MS included soil injection, chemigation, application to a leveled soil surface prior to bed formation, and application to preformed beds followed by rotovation and final bed formation. Each methodology was compared in two experiments with the current standard preplant fumigant, MBC $(67 \%$ methyl bromide: $33 \%$ chloropicrin at 336 to $448 \mathrm{~kg} / \mathrm{ha}$ ), applied at a depth of 20.3 to $22.8 \mathrm{~cm}$ using three injection chisels spaced $22.8 \mathrm{~cm}$ apart. Not all methods of 
applying MS were compared within the same experiment.

All fields were cultivated and irrigated prior to fumigation to ensure adequate soil moisture and tilth for bed formation. A background estimation of Meloidogyne spp. populations was routinely obtained through random sampling of each field before fumigation. Unless otherwise indicated, beds were $20 \mathrm{~cm}$ high, $0.9 \mathrm{~m}$ wide, and arranged on $1.8-\mathrm{m}$ centers. Following application of fumigants, beds were immediately covered with $0.032-\mathrm{mm}$-thick, black or white on gray, low-density polyethylene mulch. White mulch is customarily used for tomatoes grown during warm periods (late August through October), and black mulch is used during cooler periods (November through March) in southwest Florida. Plants were grown using a $46-\mathrm{cm}$ in-row spacing, and conventional cultural and pest management practices for commercial staked tomato production in southwest Florida were employed.

Marketable fruit were harvested one to three times depending on weather and plant conditions; the number of plants harvested varied by experiment and ranged from 10 to 40 per plot. In initial experiments, only fruit number and weight were obtained from each plot. In subsequent experiments, fruit was counted, weighed, and graded using a commercial system based on fruit size. The extra-large fruit category, defined as those fruit larger than $7 \mathrm{~cm}$ in diameter, is an especially important market parameter.

Following final harvest, 10 to 15 plants at the center of each plot were uprooted, dissected longitudinally, and rated for FCRR severity (percentage of internal crown and tap root discoloration) using a 1 to 7 rating scale where $1=0 \%, 2=1$ to $10 \%, 3=11$ to $20 \%, 4=21$ to $40 \%, 5=41$ to $60 \%, 6=61$ to $90 \%$, and $7=91$ to $100 \%$ discoloration. Tomato stem tissue of selected samples from each field was surface-disinfested in $0.5 \% \mathrm{NaOCl}$ and incu- bated on Komada's medium (13). Tomato cv. Sunny and the seedling assay of Sanchez et al. (25) were used to confirm infection by $F$. oxysporum f. sp. radicislycopersici in 5 to 6 representative samples from each field. Roots were also routinely evaluated for root-knot nematode (Meloidogyne spp.) galls using the 0 to 8 rating scheme of Daulton and Nusbaum (3). Treatment means were routinely separated using Fisher's least significant difference test (LSD) following analysis of variance (ANOVA), and in one case using contrasts (SAS Statistical Institute, Inc., Cary, NC). Where appropriate, arc sine or square root transformations were used on percentage data prior to statistical analysis (7).

Soil injection. Farm 1, 1992 to 1993. This site had been planted continuously in tomatoes for the previous 6 years, and had a soil $\mathrm{pH}$ of 6.3 and organic matter content (OMC) of $1.5 \%$. Fumigant treatments, MS (935 liters/ha) and MBC (336 kg/ha), were applied on 2 November 1992. The daily high soil temperature (measured at a standard depth of $10.2 \mathrm{~cm}$ ) at the Southwest Florida Research and Education Center (SWFREC) in Immokalee, Florida was $30.1^{\circ} \mathrm{C}$. MS was applied at a depth of 20.3 to $22.8 \mathrm{~cm}$ using 6 injection chisels spaced 10.2 to $12.7 \mathrm{~cm}$ apart. Treatments and a nontreated control were replicated six times using plots $36.5 \mathrm{~m}$ long arranged in a randomized complete block design.

Tomato cv. Agriset 761 was transplanted on 23 November. The marketable fruit from 10 plants at the center of each plot were counted and weighed on 9 and 23 February 1993. Plants were rated for FCRR on 5 March 1993.

Farm 2, 1993. This site had been planted in tomato rotated with pepper or cucumber for the preceding 7 years. The soil $\mathrm{pH}$ and OMC measured 6.6 and $0.8 \%$, respectively. Fumigant treatments, MS (935 liters/ha) and MBC (336 kg/ha), were applied on 12 January 1993. The daily high soil temperature recorded at SWFREC was $18.6^{\circ} \mathrm{C}$.
MS was applied by chisel injection as on farm 1 1992. Treatments and a nontreated control were replicated six times using plots $18.3 \mathrm{~m}$ long arranged in a randomized complete block design.

Tomato cv. Sunny was transplanted on 28 January. The marketable fruit from all 40 plants in each plot were counted and weighed on 30 April. Plants were rated for FCRR on the same date. Plants were harvested only once because of damage caused by a severe wind storm and the high incidence of bacterial spot that followed.

Chemigation and pre-bed spray application. Farm 3, field 1, 1992 to 1993. The site had been cropped in tomato rotated with squash for the previous 9 years. The soil $\mathrm{pH}$ and OMC measured 5.8 and $1.4 \%$, respectively. Fumigant treatments, MBC (448 kg/ha) and MS (701 and 935 liters/ha) were applied on 6 October and 13 to 15 October 1992 , respectively. The daily high soil temperatures recorded at SWFREC were $27.4^{\circ} \mathrm{C}$ on 6 October and 29.6 to $30.8^{\circ} \mathrm{C}$ on 13 to 15 October. MS was diluted in 227 liters water and continuously chemigated for a period of $2 \mathrm{~h}$ at 7.6 liters/min via a manifold into mulched beds through a single drip irrigation tube. The dilute MS was applied at a rate of approximately 19,000 liters/ha. The drip tube (Netafim Irrigation, Fresno, CA) had a 45.7-cm emitter spacing and was placed on the soil surface, $23 \mathrm{~cm}$ from the bed center, as per the standard irrigation practice for bed-grown tomatoes in southwest Florida. Treatments and a nontreated control were replicated five or six times using plots 30.5 $\mathrm{m}$ long arranged in a randomized complete block design.

Tomato cv. Cobia was transplanted on 27 October. The marketable fruit from 10 plants at the center of each plot were counted and weighed on 15 February 1993. Plants were rated for FCRR on the same date.

Farm 2, 1994. The experiment was located at the same site as in 1993. Fumigant

Table 1. Effect of soil injection of metam sodium on Fusarium crown rot and yield in tomato

\begin{tabular}{|c|c|c|c|c|}
\hline \multirow[b]{2}{*}{ Treatment } & \multicolumn{2}{|c|}{ Fusarium crown $\operatorname{rot}^{x}$} & \multirow[b]{2}{*}{ Fruit yield $\left(\mathrm{kg} \times 10^{3} / \mathrm{ha}\right)^{\mathrm{z}}$} & \multirow[b]{2}{*}{ Average fruit weight $(\mathrm{kg}$} \\
\hline & Incidence (\%) & Severity $(\%)^{y}$ & & \\
\hline \multicolumn{5}{|l|}{ Farm 1, 1992 to 1993} \\
\hline Nontreated control & $100 \mathrm{a}$ & $34.5 \mathrm{a}$ & $62.2 \mathrm{a}$ & $0.21 \mathrm{a}$ \\
\hline Metam sodium (935 liters/ha) & $95.0 \mathrm{ab}$ & $34.2 \mathrm{a}$ & $67.1 \mathrm{ab}$ & $0.21 \mathrm{a}$ \\
\hline Methyl bromide + chloropicrin $(336 \mathrm{~kg} / \mathrm{ha})$ & $88.3 \mathrm{~b}$ & $16.8 \mathrm{~b}$ & $69.0 \mathrm{~b}$ & $0.21 \mathrm{a}$ \\
\hline Coefficient of variance $(\%)$ & 11.0 & 29.0 & 5.8 & 5.2 \\
\hline \multicolumn{5}{|l|}{ Farm 2, 1993} \\
\hline Nontreated control & $95.0 \mathrm{a}^{*}$ & $10.5 \mathrm{~b}$ & $8.0 \mathrm{a}$ & $0.17 \mathrm{a}$ \\
\hline Metam sodium (935 liters/ha) & $96.0 \mathrm{a}$ & $15.6 \mathrm{a}$ & $8.0 \mathrm{a}$ & $0.17 \mathrm{a}$ \\
\hline Methyl bromide + chloropicrin $(336 \mathrm{~kg} / \mathrm{ha})$ & $55.0 \mathrm{~b}$ & $1.5 \mathrm{c}$ & $6.2 \mathrm{a}$ & $0.17 \mathrm{a}$ \\
\hline Coefficient of variance $(\%)$ & 30.8 & 11.4 & 23.2 & 6.9 \\
\hline
\end{tabular}

${ }^{\mathrm{x}}$ Means (within a particular column and year) followed by the same letter are not significantly different by Fisher's least significant difference test $(P \leq$ 0.05 , except $*=P<0.1$; SAS Statistical Institute, Inc., Cary, NC) following arcsine transformation. Nontransformed means are presented.

${ }^{\mathrm{y}}$ Fusarium crown rot severity was based on a 1 to 7 rating scale where $1=0 \%, 2=1$ to $10 \%, 3=11$ to $20 \%, 4=21$ to $40 \%, 5=41$ to $60 \%, 6=61$ to $90 \%$, and $7=91$ to $100 \%$ internal crown and taproot discoloration. Square root transformation was used prior to data analysis; nontransformed means are presented.

${ }^{\mathrm{z}}$ Yield data based on two harvests of 10 plants/plot or one harvest of 40 plants/plot, respectively, in the farm 1 or farm 2 experiments. The farm 2 experiment was terminated prematurely due to plant damage caused by a tropical storm. 
treatments, MBC (448 kg/ha) and MS (935 liters/ha), were applied on 19 January 1994. The daily high soil temperature recorded at SWFREC was $22.3^{\circ} \mathrm{C}$. Unlike previous and subsequent experiments, plant beds were formed on centers $1.5 \mathrm{~m}$ apart. MS was chemigated into mulched beds as outlined above, except that two drip tubes placed on the soil surface, $23 \mathrm{~cm}$ on either side of the bed center, were used in an attempt to improve the lateral distribution of the fumigant. An additional MS treatment was evaluated in which the fumigant was diluted in a small volume of water and applied to the leveled soil surface prior to bed formation (pre-bed spray application). A backpack sprayer and handheld boom equipped with two flat fan nozzles spaced $46 \mathrm{~cm}$ apart were utilized to apply the diluted fumigant at a rate of approximately 120 liters/ha. Treatments and a nontreated control were replicated six times using plots $9.1 \mathrm{~m}$ long arranged in a randomized complete block design.

Tomato cv. Olympic was transplanted on 3 February. The marketable fruit from each plant per plot (20) were counted, weighed, and graded on 28 April and 6 May. Plants were rated for FCRR on 9 May.

Pre-bed spray application and rotovation dispersal. Farm 4, 1994 to 1995. This former cattle pasture was cropped in tomato rotated with pepper for the previous 13 years. In addition to previously high incidences of Fusarium crown rot, nutsedge was a perennial problem. The soil $\mathrm{pH}$ and OMC measured 6.6 and $0.8 \%$, respectively. Because of the reported inadequate performance of MS in controlling nutsedge (6), the herbicide pebulate $(S$ Propyl butyl(ethyl)thiocarbamate) was used in combination with the fumigant. Soil treatments, MBC (403 kg/ha) and MS (935 liters/ha) plus pebulate (Tillam, 4.5 $\mathrm{kg} / \mathrm{ha}$ ), were applied on 22 November 1994. The daily high soil temperature recorded at SWFREC was $28.4^{\circ} \mathrm{C}$. Two different methods of applying MS and pebu- late were compared using a backpack sprayer and hand-held boom: (i) application to the soil surface prior to bed formation and (ii) application to a preformed bed followed by cultivation using a tractorpowered rotovator (rotovation dispersal) to a depth of 15 to $20 \mathrm{~cm}$ and final bed formation.

Tomato cv. Sunny was transplanted on 12 December. The marketable fruit from 10 plants within each plot were harvested and graded three times on 16 and 29 March and 10 April 1995. Plants were rated for FCRR on 11 April.

Farm 3, field 2, 1994 to 1995. The experiment was conducted in a different field on the same farm that was used in 1993. The cropping history of this site included rotation of tomato with squash for the previous 10 years. The soil $\mathrm{pH}$ and OMC measured 6.2 and $1.0 \%$, respectively. Fumigant treatments, MBC (336 kg/ha) and MS (935 liters/ha), were applied on 30 August 1994 . The daily high soil temperature recorded at SWFREC was $33.2^{\circ} \mathrm{C}$. MS was applied using a backpack sprayer and hand-held boom to a preformed bed, followed by rotovation dispersal to a depth of 15 to $20 \mathrm{~cm}$ and final bed formation.

Tomato cv. Agriset 761 was transplanted on 10 October. The marketable fruit from 24 plants within each plot were harvested and graded two times, on 4 and 23 January 1995. Plants were rated for FCRR on the same date.

\section{RESULTS}

The incidence of FCRR was consistently high in nontreated plots at all sites and ranged from 80 to $100 \%$, while disease severity, as represented by extent of internal crown and tap root discoloration, varied from 10.5 to $41.0 \%$ (Tables 1 to 4 ). Significant plant mortality was only observed during the experiment conducted at farm 3 , field 1 and this accounted for the high severity ratings detected at the site (Table 2). Fusarium wilt ( $F$. oxysporum $\mathrm{f}$. sp. lycopersici) and bacterial wilt (Ralstonia solanacearum) rarely were observed at any site. Tomato seedling assays consistently confirmed infection of symptomatic plants by $F$. oxysporum f. sp. radicis-lycopersici.

Application of MBC significantly reduced the incidence of FCRR at all sites in all experiments, while disease severity (crown and tap root discoloration) was decreased in four of six experiments by this fumigant (Tables 1 to 4 ). Fruit yield was significantly increased by $\mathrm{MBC}$ at farms 1, 3 (field 1), and 4 (Tables 1 to 3 ). Average fruit weight was significantly increased by the same fumigant at farm 3 (field 1) and at farm 2 (1994), while the number of extra-large fruit was significantly increased at farm 4 (Tables 2 and 3).

Soil injection and chemigation of MS using either one or two drip tubes failed to reduce either crown rot incidence or severity (Tables 1 and 2). Injection of MS (farm 2,1993 ) and chemigation of the fumigant with one drip tube (farm 3, field 1) appeared to increase the severity of the disease (Tables 1 and 2). Neither injection nor chemigation of MS increased yield, average fruit weight, or number of extra-large tomatoes. Spray application of MS to the soil prior to bed formation significantly reduced FCRR incidence in one of two experiments but did not affect disease severity in either (Tables 2 and 3). Yield and number of extra large tomatoes were significantly increased by this treatment in one experiment (Table 3). Dispersal of the fumigant by rotovation into a preformed bed significantly decreased crown rot incidence at both sites where it was evaluated (Tables 3 and 4). Disease severity was reduced at farm 4 by this method of MS application, and the fumigant also increased yield and the number of extra-large fruit (Table 3).

Phytoparasitic nematodes were not detected in any of the prefumigation samples, and root-knot damage was not detected

Table 2. Effect of chemigation and pre-bed spray application of metam sodium on Fusarium crown rot and yield in tomato

\begin{tabular}{|c|c|c|c|c|}
\hline \multirow[b]{2}{*}{ Treatment } & \multicolumn{2}{|c|}{ Fusarium crown $\operatorname{rot}^{x}$} & \multirow[b]{2}{*}{ Fruit yield $\left(\mathrm{kg} \times 10^{3} / \mathrm{ha}\right)^{\mathrm{z}}$} & \multirow[b]{2}{*}{ Average fruit weight $(\mathbf{k g})$} \\
\hline & Incidence (\%) & Severity $(\%)^{\mathrm{y}}$ & & \\
\hline \multicolumn{5}{|l|}{ Farm 3, Field 1, 1992 to 1993} \\
\hline Nontreated control & $100 \mathrm{a}$ & $41.0 \mathrm{bc}$ & $10.8 \mathrm{~b}$ & $0.13 \mathrm{~b}$ \\
\hline Metam sodium (701 liters/ha); chemigation & $100 \mathrm{a}$ & $63.4 \mathrm{ab}$ & $18.0 \mathrm{ab}$ & $0.14 \mathrm{~b}$ \\
\hline Metam sodium (935 liters/ha); chemigation & $100 \mathrm{a}$ & $73.6 \mathrm{a}$ & $11.9 \mathrm{ab}$ & $0.15 \mathrm{ab}$ \\
\hline Methyl bromide + chloropicrin (448 kg/ha) & $78.0 \mathrm{~b}$ & $23.6 \mathrm{c}$ & $18.9 \mathrm{a}$ & $0.16 \mathrm{a}$ \\
\hline Coefficient of variance (\%) & 28.6 & 13.6 & 20.8 & 9.0 \\
\hline \multicolumn{5}{|l|}{ Farm 2, 1994} \\
\hline Nontreated control & $100 \mathrm{a}^{*}$ & $25.6 \mathrm{a}$ & $45.1 \mathrm{a}$ & $0.19 \mathrm{~b}$ \\
\hline Metam sodium (935 liters/ha); chemigation & $91.8 \mathrm{a}$ & $19.3 \mathrm{a}$ & $40.7 \mathrm{a}$ & $0.18 \mathrm{~b}$ \\
\hline Metam sodium (935 liters/ha); pre-bed spray & $77.3 \mathrm{~b}$ & $17.5 \mathrm{a}$ & $43.2 \mathrm{a}$ & $0.18 \mathrm{~b}$ \\
\hline Methyl bromide + chloropicrin (403 kg/ha) & $85.6 \mathrm{~b}$ & $13.5 \mathrm{a}$ & $43.5 \mathrm{a}$ & $0.20 \mathrm{a}$ \\
\hline Coefficient of variance $(\%)$ & 38.2 & 19.5 & 13.2 & 3.8 \\
\hline
\end{tabular}


following final harvest at five of the six sites. In the one experiment where rootknot damage was detected (farm 3, field 2), it occurred at a low incidence and very low severity (Table 5). Both MS and MBC produced nonsignificant decreases in root gall incidence, and MS resulted in a significant decrease in root gall index as determined by contrasts following ANOVA (Table 5). Nutsedge incidence was too low to evaluate except at farm 4, where both MS and pebulate treatments significantly reduced the incidence of the weed (Table 3).

\section{DISCUSSION}

Variations in FCRR severity between experiments did not appear to be related to previous cropping history or rainfall; precipitation was consistently above average during each period. However, crown rot severity was highest in those experiments planted from late October through midDecember. These planting schedules presumably allowed for plant growth and fruit maturation during a cooler, more favorable period for disease development than those which occurred with either earlier or later plantings. It has been demonstrated that symptom expression by FCRR is favored by cool temperatures in the range of 18 to $25^{\circ} \mathrm{C}(10,24)$, which are commonly encountered during mid-winter in south Florida. Divergences in FCRR from site to site may also have resulted from differ- ences in inoculum densities, susceptibility among tomato cultivars to $F$. oxysporum $\mathrm{f}$. sp. radicis-lycopersici, edaphic factors, or a combination of these. It is noteworthy with regard to the last point that the highest FCRR severity, including the only appearance of significant plant mortality, occurred at the site (farm 3, field 1, 1993) with the lowest $\mathrm{pH}$ (5.8), supporting previous observations that low soil $\mathrm{pH}$ (5.2 to 6.1) exacerbates the disease (11).

The failure of MS to reduce FCRR when applied by means of either injection or chemigation and the variable results obtained with pre-bed spray application of the fumigant is in agreement with previous research (11) and may have resulted from insufficient fumigant distribution in the treated soils. Methylisothiocyanate (MITC), a conversion product and the bioactive agent of MS (19), exhibits characteristics which may lead to its nonuniform lateral distribution in the targeted planting zone $(5,27)$. The end result of MS's inherent nonuniform movement may be the treatment of unacceptably narrow bands of soil $(1,21)$. The increase in disease severity encountered with injection and chemigation of MS at two sites may have been due to a reduction of naturally occurring microorganisms which are suppressive to F. oxysporum f. sp. radicis-lycopersici in combination with inadequate elimination of the pathogen.
The effectiveness of chemigation with MS may be enhanced by burying the drip tube(s) in the bed; root-knot nematode indices were significantly reduced in tomato by applying MS through buried irrigation tubes $(20,22)$. Using a drip tube with a closer emitter spacing could aid in increasing MS distribution but would also increase tube cost. Other options for improving the disease-suppressive capability of chemigation include the use of narrower planting beds to reduce the treated soil volume and additional drip tubes. While the former measure may reduce production costs as long as yield is unimpaired, the latter option would represent an added expense. Improving the distribution of MS during injection may be theoretically achieved by increasing the number of chisels through which MS is injected, as well as incorporating multiple injection depths, but this strategy may be physically impractical in some highly compacted soils.

On the other hand, application methods which increase soil aeration during fumigation increase conversion of MS to MITC (30). Rotovation dispersal proved to be a consistently effective methodology for MS, presumably because of increased fumigant distribution through such increased aeration of soil. Large-scale implementation of this MS application method may be possible by retrofitting tractor-drawn bedders with spray and rotovation equipment or,

Table 3. Effect of rotovation dispersal and pre-bed spray application of metam sodium and pebulate on crown rot and yield in tomato at farm 4 , 1994 to 1995

\begin{tabular}{|c|c|c|c|c|c|}
\hline \multirow[b]{2}{*}{ Treatment } & \multicolumn{2}{|c|}{ Fusarium crown $\operatorname{rot}^{\mathrm{x}}$} & \multirow{2}{*}{$\begin{array}{c}\text { No. nutsedge } \\
\text { plants/plot }\end{array}$} & \multirow{2}{*}{$\begin{array}{c}\text { Fruit yield }^{\mathrm{z}} \\
\left(\mathrm{kg} \times \mathbf{1 0}^{\mathbf{3}} / \mathrm{ha}\right)\end{array}$} & \multirow{2}{*}{$\begin{array}{l}\text { No. extra-large } \\
\text { fruit/ha } \times 10^{3}\end{array}$} \\
\hline & Incidence (\%) & Severity $(\%)^{y}$ & & & \\
\hline Nontreated control & $100 \mathrm{a}$ & $36.8 \mathrm{a}$ & $16.6 \mathrm{a}$ & $41.9 \mathrm{~b}$ & $15.1 \mathrm{~b}$ \\
\hline $\begin{array}{l}\text { Metam sodium (935 liters } / \mathrm{ha})+ \text { Pebulate }(4.5 \mathrm{~kg} / \mathrm{ha}) \text {; } \\
\text { pre-bed spray }\end{array}$ & $78.0 \mathrm{ab}$ & $27.6 \mathrm{a}$ & $0.6 \mathrm{~b}$ & 50.9 a & $24.6 \mathrm{a}$ \\
\hline $\begin{array}{l}\text { Metam sodium (935 liters/ha) + Pebulate }(4.5 \mathrm{~kg} / \mathrm{ha}) \text {; } \\
\text { rotovation }\end{array}$ & $55.0 \mathrm{bc}$ & $6.5 \mathrm{~b}$ & $0.0 \mathrm{~b}$ & $57.3 \mathrm{a}$ & $33.5 \mathrm{a}$ \\
\hline Methyl bromide + chloropicrin (392 kg/ha) & $30.0 \mathrm{bc}$ & $4.0 \mathrm{~b}$ & $2.2 \mathrm{~b}$ & $54.8 \mathrm{a}$ & $25.7 \mathrm{a}$ \\
\hline Coefficient of variance (\%) & 40.2 & 36.7 & 145.6 & 11.8 & 26.2 \\
\hline
\end{tabular}

${ }^{\mathrm{x}}$ Means within columns followed by the same letter are not significantly different by Fisher's least significant difference test $(P \leq 0.05$, SAS Statistical Institute, Inc., Cary, NC) following arcsine transformation. Nontransformed means are presented.

${ }^{\mathrm{y}}$ Fusarium crown rot severity was based on a 1 to 7 rating scale where $1=0 \%, 2=1$ to $10 \%, 3=11$ to $20 \%, 4=21$ to $40 \%, 5=41$ to $60 \%, 6=61$ t o $90 \%$, and $7=91$ to $100 \%$ internal crown and taproot discoloration. Arcsine transformation was used prior to data analysis; nontransformed means are presented.

${ }^{\mathrm{z}}$ Yield data based on three harvests of 10 plants/plot.

Table 4. Effect of rotovation dispersal of metam sodium on Fusarium crown rot, and yield in tomato at farm 3, field 2, 1994 to $1995^{\mathrm{w}}$

\begin{tabular}{|c|c|c|c|c|}
\hline \multirow[b]{2}{*}{ Treatment } & \multicolumn{2}{|c|}{ Fusarium crown rot } & \multirow[b]{2}{*}{ Fruit yield $\left(\mathrm{kg} \times 10^{3} / \mathrm{ha}\right)^{\mathrm{z}}$} & \multirow[b]{2}{*}{ No. extra-large fruit/ha $\times 10^{3}$} \\
\hline & Incidence $(\%)^{x}$ & Severity $(\%)^{y}$ & & \\
\hline Nontreated control & $806 a$ & $11.6 \mathrm{a}$ & $28.2 \mathrm{a}$ & $31.0 \mathrm{a}$ \\
\hline ovation (935 lite & & & & \\
\hline Methyl bromide + chloropicri & $37.5 \mathrm{~b}$ & $3.0 \mathrm{~b}$ & $29.8 \mathrm{a}$ & $40.7 \mathrm{a}$ \\
\hline Coefficient of variance (\%) & 19.0 & 28.7 & 6.9 & 28.4 \\
\hline \multicolumn{5}{|c|}{$\begin{array}{l}\text { "Means within columns followed by the same letter are not significantly different by Fisher's least significant difference test }(P \leq 0.05 \text {, SAS Statistical } \\
\text { Institute, Inc., Cary, NC). } \\
\text { x Arcsine transformation was used prior to data analysis. Nontransformed means are presented. }\end{array}$} \\
\hline \multicolumn{5}{|c|}{$\begin{array}{l}\text { y Fusarium crown rot severity was based on a } 1 \text { to } 7 \text { rating scale where } 1=0 \%, 2=1 \text { to } 10 \%, 3=11 \text { to } 20 \%, 4=21 \text { to } 40 \%, 5=41 \text { to } 60 \%, 6=61 \text { to } 90 \% \text {, } \\
\text { and } 7=91 \text { to } 100 \% \text { internal crown and taproot discoloration. Square root transformation was used prior to data analysis. Nontransformed means are } \\
\text { presented. } \\
\text { z Yield data based on two harvests of } 24 \text { plants/plot. }\end{array}$} \\
\hline
\end{tabular}


more simply, but perhaps less economically, through the use of an additional device to apply and rotovate-disperse the fumigant prior to final bed formation.

The absence of detectable populations of both root-knot nematodes and nutsedge at most experimental sites suggests suppression of these pests by previous, longstanding use of MBC. While reduction of nutsedge by a combination of MS and pebulate and reduction in root knot damage by MS alone appear promising, these results must be viewed as preliminary. Further testing is necessary to determine the efficacy of MS plus pebulate (and other potential methyl bromide replacements) at other commercial sites with higher populations of root-knot nematodes and nutsedge. It is essential that experiments be conducted on the same commercial sites over multiple years in order to assess fumigant effectiveness against other pests that may rebound after numerous years of suppression by MBC.

Fumigation for reduction of soilborne plant diseases cannot be viewed in a vacuum but must be integrated with other measures to be most effective. Pathogenfree transplants and optimal cultural practices are essential components in an integrated approach to reducing FCRR in tomato $(15,17,18)$. Resistance to $F$. oxysporum $\mathrm{f}$. $\mathrm{sp}$. radicis-lycopersici in a commercial field-type tomato and reduction of FCRR by biological control agents have been demonstrated $(2,14,16,26)$. Combining soil solarization with application of MS resulted in reductions of FCRR in tomato (18) and inoculum densities of Verticillium dahliae and Phytophthora cactorum (8) equivalent to those achieved by $\mathrm{MBC}$, and this integrated approach may prove useful against other soilborne pests.

\section{ACKNOWLEDGMENTS}

We thank Bonita Packing Company, Pacific Land Company, Regency Farms, R. S. \& Sons Farms, and Six L's Farms for their generosity in providing land and personnel for this work; D. Rockers and the SWFREC farm staff, F. Ligas, L. McKay, J. Kendall, and R. McGill, for technical support; and R. McSorley, G. Somodi, and J. Polston for critical review of the manuscript.

Table 5. Effect or rotovation dispersal of metam sodium on root gall incidence and index in tomato at farm 3, field 2, 1994

\begin{tabular}{lcc}
\hline Treatment & $\begin{array}{c}\text { Root gall } \\
\text { incidence }(\boldsymbol{\%})^{\mathbf{x}}\end{array}$ & $\begin{array}{c}\text { Root gall } \\
\text { index }(\boldsymbol{\%})^{\mathbf{y}}\end{array}$ \\
\hline Nontreated control & 10.4 & 0.10 \\
Metam sodium (MS; 935 liters/ha); rotovation & 2.4 & 0.02 \\
Methyl bromide + chloropicrin (MBC; 336 kg/ha) & 2.4 & 0.06 \\
Contrasts: & & \\
Control versus MS & NS & $\ldots^{\mathrm{z}}$ \\
Control versus MBC & NS & NS \\
Control versus MS and MBC & NS & NS \\
MS versus MBC & NS & NS \\
\hline
\end{tabular}

${ }^{\mathrm{x}}$ Square root transformation was used prior to data analysis; nontransformed means are presented.

${ }^{\mathrm{y}}$ The 0 to 8 root gall index of Daulton and Nusbaum (1961) was used.

${ }^{\mathrm{z}} \ldots=$ significant contrast at $P \leq 0.05 ; \mathrm{NS}=$ contrast not significant at $P \leq 0.05$.
Res. Conf. on Methyl Bromide Alternatives and Emissions Reductions. Orlando, FL.

16. McGovern, R. J., Datnoff, L. E., and Vavrina, C. S. 1993. Evaluation of seven tomato genotypes for resistance to Fusarium oxysporum f. sp. radicis-lycopersici. Phytopathology 83:1395.

17. McGovern, R. J., Vavrina, C. S., and McKay, L. A. 1993. Effect of transplant tray type and tomato cultivar on the incidence of Fusarium crown and root rot in tomato transplants. Fla. State Hortic. Soc. Proc. 106:173-175.

18. McGovern, R. J., Vavrina, C. S., Obreza, T. A., and Capece, J. C. 1995. Reduction of Fusarium crown and root rot of tomato by combining soil solarization and metam sodium. Pages 34/1-4 in: Ann. Int. Res. Conf. on Methyl Bromide Alternatives and Emissions Reductions. San Diego, CA.

19. Munnecke, D. E., Domasch, K. H., and Eckert, J. W. 1962. Fungicidal activity of air passed through columns of soil treated with fungicides. Phytopathology 52:1298-1306.

20. Overman, A. J. 1982. Soil fumigation via drip irrigation under full-bed mulch culture for row crops. Proc. Soil Crop Sci. Soc. Fla. 41:153-155.

21. Overman, A. J., Csizinsky, A. A., Jones, J. P., and Stanley, C. D. 1987. Efficacy of metam sodium applied via drip irrigation on tomato Proc. Soil Crop Sci. Soc. Fla. 46:4-7.

22. Overman, A. J., and Price, J. F. 1983. Application of pesticides via drip irrigation to control nematodes and foliar arthropods. Proc. Soil Crop Sci. Soc. Fla. 42:92-96.

23. Roberts, P. A., Mayorosy, A. C., Matthews, W. C., and May, D. M. 1988. Effects of metam-sodium applied by drip irrigation on root-knot nematodes, Pythium ultimum, and Fusarium spp. in soil and on carrot and tomato roots. Plant Dis. 72:213-217.

24. Rowe, R. C., Farley, J. D., and Coplin, D. L. 1977. Airborne spore dispersal and recolonization of steamed soil by Fusarium oxysporum in tomato greenhouses. Phytopathology 67:1513-1517.

25. Sanchez, L. E., Endo, R. M., and Leary, J. V. 1975. A rapid technique for identifying clones of Fusarium oxysporum f. sp. radicis-lycopersici causing crown- and root-rot of tomato. Phytopathology 65:726-727.

26. Sivan, A., Ucko, O., and Chet, I. 1987. Biological control of Fusarium crown rot of tomato by Trichoderma harzianum under field conditions. Plant Dis. 71:587-592.

27. Smelt, J. H., and Liestra, M. 1974. Conversion of metham-sodium to methyl isothiocyanate and basic data on the behavior of methyl isothiocyanate in soil. Pestic. Sci. 5:401-407.

28. Sonoda, R. M. 1976. The occurrence of a Fusarium root rot of tomatoes in South Florida. Plant Dis. Rep. 60:271-274.

29. Sumner, D. R., and Phatak, S. C. 1988. Efficacy of metam-sodium applied through overhead sprinkler irrigation for control of soilborne fungi and root diseases of vegetables. Plant Dis. 72:160-166.

30. Turner, N. J., and Corden, M. E. 1963. Decomposition of sodium n-methyl-dithiocarbamate in soil. Phytopathology 53:13881394.

31. U. S. Environ. Prot. Agency. 1993. 40 C FR Part 82, Protection of stratospheric ozone: Final rule making. Fed. Regis. 58(236):65018 65062.

32. Watson, R. T., Albritton, D. L., Anderson, S. O., and Lee-Bapty, S. 1992. Methyl bromide: Its atmospheric science, technology and economics. Montreal Protocol Assessment Suppl., United Nations Environmental Programme on Behalf of the Contracting Parties to the Montreal Protocol. Nairobi, Kenya. 